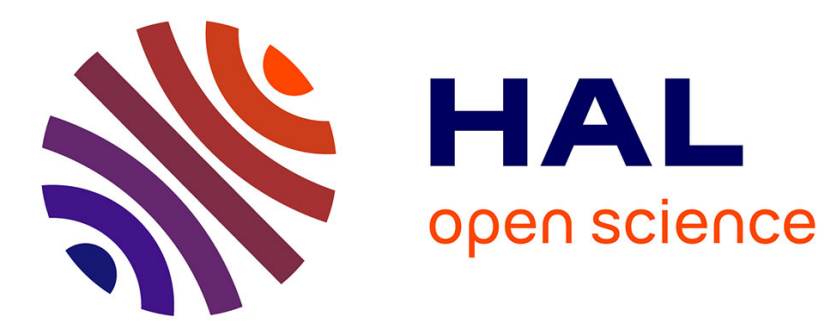

\title{
Elaboration of a bioclimatic house in the humid tropical region: Case of the town of Douala-Cameroon
}

\author{
Thomas Nganya, Bruno Ladevie, Alexis Kemajou, Léopold Mba
}

\section{To cite this version:}

Thomas Nganya, Bruno Ladevie, Alexis Kemajou, Léopold Mba. Elaboration of a bioclimatic house in the humid tropical region: Case of the town of Douala-Cameroon. Energy and Buildings, 2012, 54, pp.105 - 110. 10.1016/j.enbuild.2012.07.025 . hal-01651383

\section{HAL Id: hal-01651383 https://imt-mines-albi.hal.science/hal-01651383}

Submitted on 7 Nov 2019

HAL is a multi-disciplinary open access archive for the deposit and dissemination of scientific research documents, whether they are published or not. The documents may come from teaching and research institutions in France or abroad, or from public or private research centers.
L'archive ouverte pluridisciplinaire HAL, est destinée au dépôt et à la diffusion de documents scientifiques de niveau recherche, publiés ou non, émanant des établissements d'enseignement et de recherche français ou étrangers, des laboratoires publics ou privés. 


\title{
Elaboration of a bioclimatic house in the humid tropical region: Case of the town of Douala-Cameroon
}

\author{
Thomas Nganya $^{\mathrm{a}, *}$, Bruno Ladevie ${ }^{\mathrm{a}}$, Alexis Kemajou ${ }^{\mathrm{b}}$, Léopold Mba ${ }^{\mathrm{b}}$ \\ a Université de Toulouse, Mines Albi, CNRS, Centre RAPSODEE, FRE 3213, Campus Jarlard, F-81013 Albi Cedex, France \\ ${ }^{\mathrm{b}}$ Laboratoire de Thermique et Environnement de l'Ecole Normale Supérieure d'Enseignement Technique (ENSET), Université de Douala, B.P 1872 Douala, Cameroon
}

Keywords:

Housing

Bioclimatic

Thermal comfort

Energy consumption

\begin{abstract}
A B S T R A C T
Modelling and simulation of a habitat sample lead to a model which the average resultant dry temperature is of $28.30^{\circ} \mathrm{C}$ at the peak hours during the periods of occupation of the house. This result is within the acceptable and tolerable thermal comfort zone in humid tropical climate. It thus arises from this study, that housing with the following specifications: cement floor, wall with mixed hollow concrete block and wood plank, and roof with aluminium sheet is thermally well adapted for the Douala climate. Optimization of the thermal behaviour of this housing consists of bringing vegetation around it in order to reduce the thermal loads due to solar heat gain, improving the air replacement and taking into account the thermal inertia of its walls.
\end{abstract}

\section{Introduction}

Cameroonians generally use local materials available in their region of residence to build their houses. A survey from the National Institute of Statistics of Cameroon (I.N.S. \& ECAM II) [1] showed that three quarters of household live in houses with walls made in provisional materials like wood plank, rough soil brick, straw mat. This survey also showed that the same proportion live under the threshold of poverty.

In poor developing countries, where building a house is very expensive and where energy is rare and expensive, there is a strong need to develop a policy for construction of sustainable residential building.

The aim of this work was to elaborate a mathematical model of a sustainable residential house in the town of Douala in Cameroon that would integrate a thermal comfort goal in its design and realization. The present paper describes the thermal comfort factors as described and studied in this work, an analysis of residential housing in Douala, results of simulations and discussion.

\section{Thermal comfort conditions in humid climate}

The opinions of some Cameroonians have been surveyed on the ambient comfort of their non-air-conditioned houses [2]. Physical parameters of ambient air in their housings were simultaneously

\footnotetext{
* Corresponding author. Tel.: +33 563493093.

E-mail address: Thomas.nganya@mines-albi.fr (T. Nganya).
}

measured. Regression curves between temperature and relative humidity of air and their own judgement. This investigation showed that Cameroonians seem to endure warmer ambient air conditions than people from Northern countries (Americans, and Danish) whom opinions have been used to establish ergonomic norms ISO 7730 and ASHRAE 55-81 [2].

Results obtained in buildings non-air-conditioned allowed to deduce that a suitable design of housing could make the airconditioning systems useless [3].

Acceptable and tolerable thermal comfort ranges have been found and can be used to design sustainable houses in humid tropical zone for three towns in Cameroon (Yaounde, Douala and Bafoussam) [4]. These conditions are grouped in Table 1 [2].

It should be noted that the ideal conditions for sustainable housing design "bioclimatic house" will be to obtain temperature in the optimal comfort zone in humid tropical climate $\left(T_{o p}=28.1^{\circ} \mathrm{C}\right.$ for the town of Douala) [2].

In this present study, we will take in consideration a fundamental factor to characterize the concept of thermal comfort: the dry resultant temperature, which is the essential criteria of the comfort defined by A. Missenard by the following relation:

$T_{r s}=\frac{T_{r m}+T_{a i} \sqrt{10 W}}{1+\sqrt{10 W}}$.

We will also take into consideration the velocity of air $(W)$ that plays an important role in the feeling of comfort by people. This parameter controls the heat flux between the body and the ambience. The upper and lower limits applied for air velocities are: $1.5 \mathrm{~m} / \mathrm{s}$ for sensation and $0.2 \mathrm{~m} / \mathrm{s}$ at the beginning [5]. 


\begin{tabular}{|c|c|}
\hline \multicolumn{2}{|c|}{ Nomenclature } \\
\hline$q_{t e}$ & solar flux on the roofing, $\mathrm{W} / \mathrm{m}^{2}$ \\
\hline$q_{o e}$ & solar flux on the openings, $\mathrm{W} / \mathrm{m}^{2}$ \\
\hline$q_{m e}$ & solar flux on the walls, $\mathrm{W} / \mathrm{m}^{2}$ \\
\hline$k$ & thermal conductance, $\mathrm{W} / \mathrm{K}$ \\
\hline C & thermal capacity, $\mathrm{J} / \mathrm{K}$ \\
\hline$W$ & speed, $\mathrm{m} / \mathrm{s}$ \\
\hline$T_{a e}$ & external ambient air temperature, $\mathrm{K}$ \\
\hline$T_{t e}$ & $\begin{array}{l}\text { temperature of external side of roofing at node } 1 \text { in } \\
\text { Fig. } 1, \mathrm{~K}\end{array}$ \\
\hline$T_{t i}$ & $\begin{array}{l}\text { temperature of internal side of roofing at node } 2 \text { in } \\
\text { Fig. } 1, K\end{array}$ \\
\hline$T_{o e}$ & $\begin{array}{l}\text { temperature of external side of openings at node } 3 \\
\text { in Fig. } 1, \mathrm{~K}\end{array}$ \\
\hline$T_{o i}$ & $\begin{array}{l}\text { temperature of internal side of openings at node } 4 \\
\text { in Fig. } 1, \mathrm{~K}\end{array}$ \\
\hline$T_{m e}$ & $\begin{array}{l}\text { temperature of external side of walls at node } 5 \text { in } \\
\text { Fig. } 1, K\end{array}$ \\
\hline$T_{m i}$ & $\begin{array}{l}\text { temperature of internal side of walls at node } 6 \text { in } \\
\text { Fig. } 1, \mathrm{~K}\end{array}$ \\
\hline$T_{s e}$ & $\begin{array}{l}\text { temperature of external side of ground at node } 7 \text { in } \\
\text { Fig. } 1, K\end{array}$ \\
\hline$T_{s i}$ & $\begin{array}{l}\text { temperature of internal side of ground at node } 8 \text { in } \\
\text { Fig. } 1, K\end{array}$ \\
\hline$T_{a i}$ & $\begin{array}{l}\text { internal ambient air temperature at node } 9 \text { in Fig. } 1 \text {, } \\
\mathrm{K}\end{array}$ \\
\hline$T_{r m}$ & radiant average temperature at node 10 in Fig. $1, \mathrm{~K}$ \\
\hline$S_{m}$ & wall surface, $\mathrm{m}^{2}$ \\
\hline$S_{t e}$ & external roofing surface, $\mathrm{m}^{2}$ \\
\hline$S_{0}$ & openings surface, $\mathrm{m}^{2}$ \\
\hline$S_{S}$ & ground surface, $\mathrm{m}^{2}$ \\
\hline$S_{t i}$ & ceiling surface, $\mathrm{m}^{2}$ \\
\hline$V_{a i}$ & volume of internal air of housing, $\mathrm{m}^{3}$ \\
\hline$h_{t}$ & height, $\mathrm{m}$ \\
\hline$e$ & thickness, m \\
\hline$L$ & length, m \\
\hline$\ell$ & width, m \\
\hline$\lambda$ & thermal conductivity, $\mathrm{W} /(\mathrm{m} \mathrm{K})$ \\
\hline$\rho$ & density, $\mathrm{kg} / \mathrm{m}^{3}$ \\
\hline c & specific heat, kJ/(kg K) \\
\hline
\end{tabular}

\section{Analysis of existing types of housing in the town of Douala}

Studies carried on by I.N.S. \& ECAM II [1] on the types of houses in Douala enabled to classify housings according to the building materials used.

\subsection{Distribution of Cameroonian housings}

The distribution of building materials used (roof, wall, floor) in Cameroonian housings is showed in Table 2 [1].
This distribution shows that in the majority of housings in Douala, the roof is in aluminium sheet, the wall in wood plank or hallow concrete block and the floor is in cement.

These materials were chose for the design of a house model used for simulation. The house had the following dimensions: height under ceiling: $2.5 \mathrm{~m}$, length: $5 \mathrm{~m}$ and width: $5 \mathrm{~m}$, with simple glazing windows.

\subsection{House thermal node model}

Fig. 1 represents the thermal nodal model of the studied house model.

To better analyse the thermal behaviour of the house, the latter is represented through an electrical analogy, matching the thermal to electrical parameters.

Applying the Kirchhoff's first law at the different nodes of the diagram, we obtain ordinary differential equations:

$C_{t e} \frac{d T_{t e}}{d t}=-\left(k_{t e}+k_{t}\right) T_{t e}+k_{t e} T_{a e}+k_{t} T_{t i}+q_{t e}$

$C_{t i} \frac{d T_{t i}}{d t}=-\left(k_{t}+k_{t c i}+k_{t r i}\right) T_{t i}+k_{t} T_{t e}+k_{t c i} T_{a i}+k_{t r i} T_{r m}$

$C_{o e} \frac{d T_{o e}}{d t}=-\left(k_{o}+k_{o e}\right) T_{o e}+k_{o e} T_{a e}+q_{o e}+k_{o} T_{o i}$

$C_{o i} \frac{d T_{o i}}{d t}=-\left(k_{o}+k_{o c i}+k_{o r i}\right) T_{o i}+k_{o} T_{o e}+k_{o c i} T_{a i}+k_{o r i} T_{r m}$

$C_{m e} \frac{d T_{m e}}{d t}=-\left(k_{m e}+k_{m}\right) T_{m e}+k_{m e} T_{a e}+k_{m} T_{m i}+q_{m e}$

$C_{m i} \frac{d T_{m i}}{d t}=-\left(k_{m}+k_{m r i}+k_{m c i}\right) T_{m i}+k_{m} T_{m e}+k_{m c i} T_{a i}+k_{m r i} T_{r m}$

$C_{s e} \frac{d T_{s e}}{d t}=-\left(k_{s}\right) T_{s e}+k_{s} T_{s i}$

$C_{s i} \frac{d T_{s i}}{d t}=-\left(k_{s}+k_{s c i}+k_{s r i}\right) T_{s i}+k_{s} T_{s e}+k_{s c i} T_{a i}+k_{s r i} T_{r m}$

$C_{a i} \frac{d T_{a i}}{d t}=-\left(k_{t c i}+k_{o c i}+k_{m c i}+k_{s c i}+k_{r a}\right) T_{a i}+k_{t c i} T_{t i}+k_{o c i} T_{o i}$

$$
+k_{m c i} T_{m i}+k_{s c i} T_{s i}+k_{r a} T_{a e}
$$

$T_{r m}=\frac{k_{t r i} T_{t i}+k_{o r i} T_{o i}+k_{s r i} T_{s i}+k_{m r i} T_{m i}}{k_{t r i}+k_{o r i}+k_{s r i}+k_{m r i}}$

That can be rewritten as thus:

$C \frac{d T}{d t}+K T=E$

That is:

$\frac{C}{K} \frac{d T}{d t}+T=\frac{E}{K}$

Of whom analytical solution is written as:

$T(t)=\frac{E}{K}+\left(T_{o}-\frac{E}{K}\right) * \exp \left(-\frac{t}{C / K}\right)$

where $t$ stand for time in second $(\mathrm{s})$.

Table 1

Thermal comfort zone for some Cameroonian towns.

\begin{tabular}{|c|c|c|c|}
\hline City & Yaounde & Douala & Bafoussam \\
\hline Acceptable thermal comfort zone (satisfaction index $=80 \%$ ) & $\begin{array}{c}25.1^{\circ} \mathrm{C} \leq T_{0} \leq 29.5^{\circ} \mathrm{C} \\
H_{r}=72 \% \text { with } 25.1^{\circ} \mathrm{C} \\
H_{r}=51.4 \% \text { with } 29.5^{\circ} \mathrm{C}\end{array}$ & $\begin{aligned} \cdots T_{0} & \leq 29.4{ }^{\circ} \mathrm{C} \\
& H_{r}=71 \% \text { with } 29.4^{\circ} \mathrm{C}\end{aligned}$ & $\begin{aligned} 23.3^{\circ} \mathrm{C} \leq T_{0} \leq 28.2^{\circ} \mathrm{C} \\
H_{r}=69.7 \% \text { with } 23.3^{\circ} \mathrm{C} \\
H_{r}=37.2 \% \text { with } 28.2^{\circ} \mathrm{C}\end{aligned}$ \\
\hline Bearable thermal comfort zone (satisfaction index $=70 \%$ ) & $\begin{aligned} 24.5^{\circ} \mathrm{C} \leq T_{0} \leq 30.5^{\circ} \mathrm{C} \\
H_{r}=74.7 \% \text { with } 24.5^{\circ} \mathrm{C} \\
H_{r}=45.9 \% \text { with } 30.5^{\circ} \mathrm{C}\end{aligned}$ & $\begin{aligned} \cdots T_{0} & \leq 29.4^{\circ} \mathrm{C} \\
H_{r} & =71 \% \text { with } 29.4^{\circ} \mathrm{C}\end{aligned}$ & $\begin{aligned} 20.7^{\circ} \mathrm{C} \leq T_{0} \leq 30.4^{\circ} \mathrm{C} \\
H_{r}=87 \% \text { with } 20.7^{\circ} \mathrm{C} \\
H_{r}=22.6 \% \text { with } 30.4^{\circ} \mathrm{C}\end{aligned}$ \\
\hline
\end{tabular}


Table 2

Building materials distribution in the littoral region (Douala).

\begin{tabular}{|c|c|c|c|c|c|c|c|}
\hline \multicolumn{8}{|c|}{ Materials (\%) } \\
\hline Roof & Cement $1.3 \%$ & Aluminium sheet/tile $98 \%$ & Others $0.7 \%$ & & & & \\
\hline Wall & Hallow block concrete $34.4 \%$ & Stones $0.3 \%$ & Plank 39.8\% & Wood $12.8 \%$ & Brick of earth $4.3 \%$ & Others bricks $6.8 \%$ & Others $1.8 \%$ \\
\hline Floor & Cement 56.4\% & Wood $0.1 \%$ & Earth $41.8 \%$ & Others $1.7 \%$ & & & \\
\hline
\end{tabular}

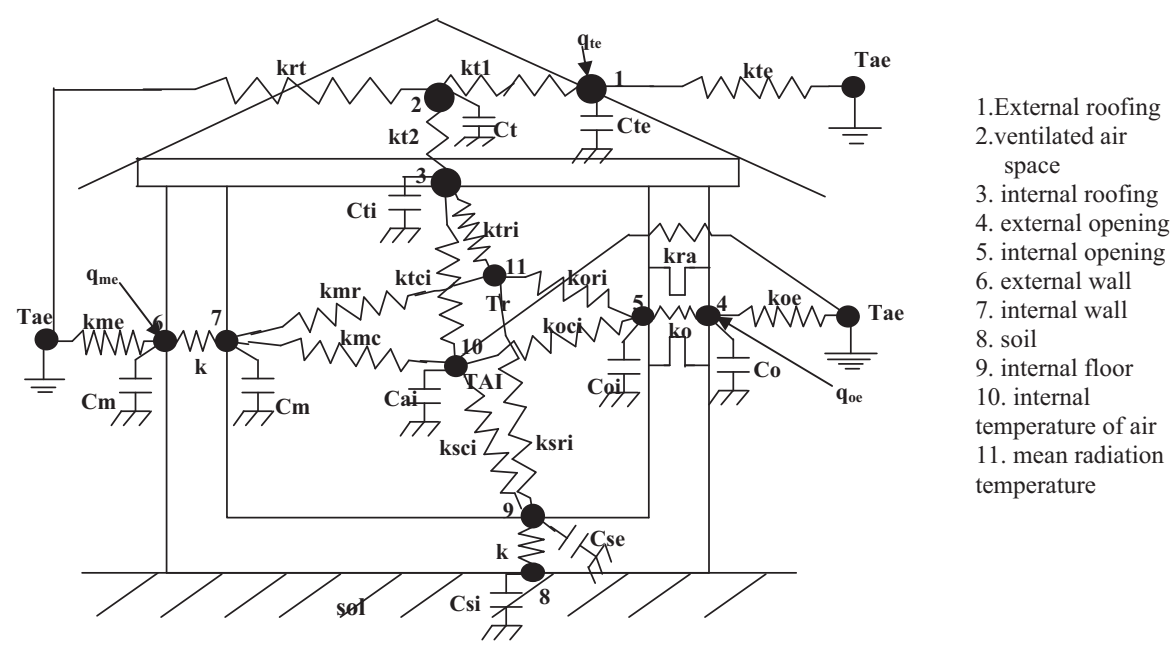

Fig. 1. Thermal node model of house and its electrical analogy.

\subsection{Simulation of the thermal behaviour of housing sample}

According to I.N.S. \& ECAM II's classification [1], three types of housing have been retained for the simulation, through the building materials of walls. They are grouped as follows:

- Type 1: roof in aluminium sheet, wall in wood plank, floor in cement.

- Type 2: roof in aluminium sheet, wall in hollow concrete block, floor in cement.

- Type 3: roof in aluminium sheet, wall in clay brick, floor in cement.

The thermal behaviour of the three types of house was studied. Some data necessary for the simulation are common to all the houses, and are known as "fixed data", while some are particular to each house and are called "variable data".

\subsubsection{Fixed data}

The geometrical dimensions of the house sample such as: the wall length, width and height are fixed throughout all simulations.
These data allow the computation of some of the thermal conductance and capacitance which do not vary during the simulation process.

\subsubsection{Variable data}

Variable data are the material thickness and thermo-physical properties of building materials (thermal conductivity, density, specific heat) which may change according to the materials chosen for the simulations [6-9].

The materials studied were concrete blocks wall, clay brick wall and wood plank wall.

\section{Results of the simulation}

4.1. Diagrams: evolution of the temperature in function of time in the model house (Figs. 2-5)

The simulation consisted in solving Eq. (13) by using the "MATLAB" software [9]. It also enabled the determination of the resulting

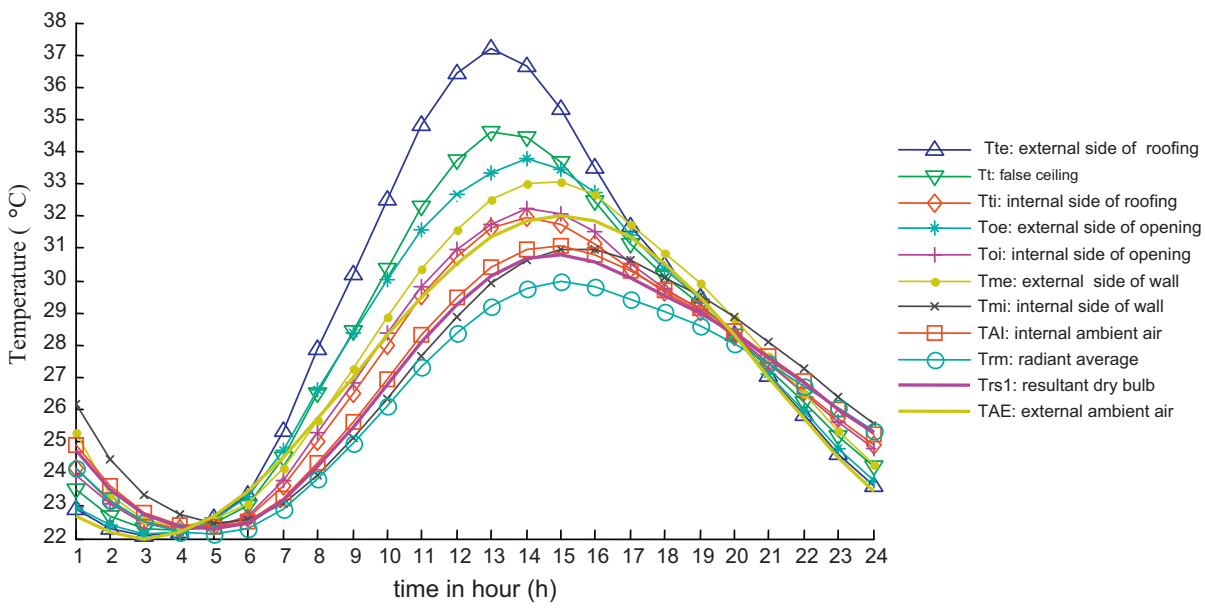

Fig. 2. Temperature profile with wood plank. 


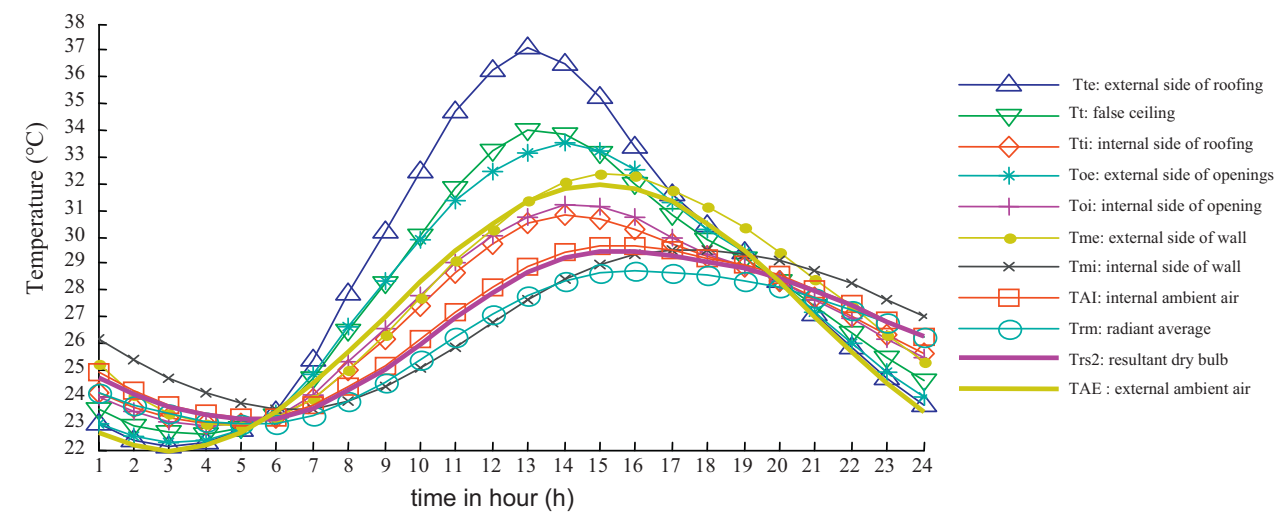

Fig. 3. Temperature profile with hollow concrete block + cement mortar.

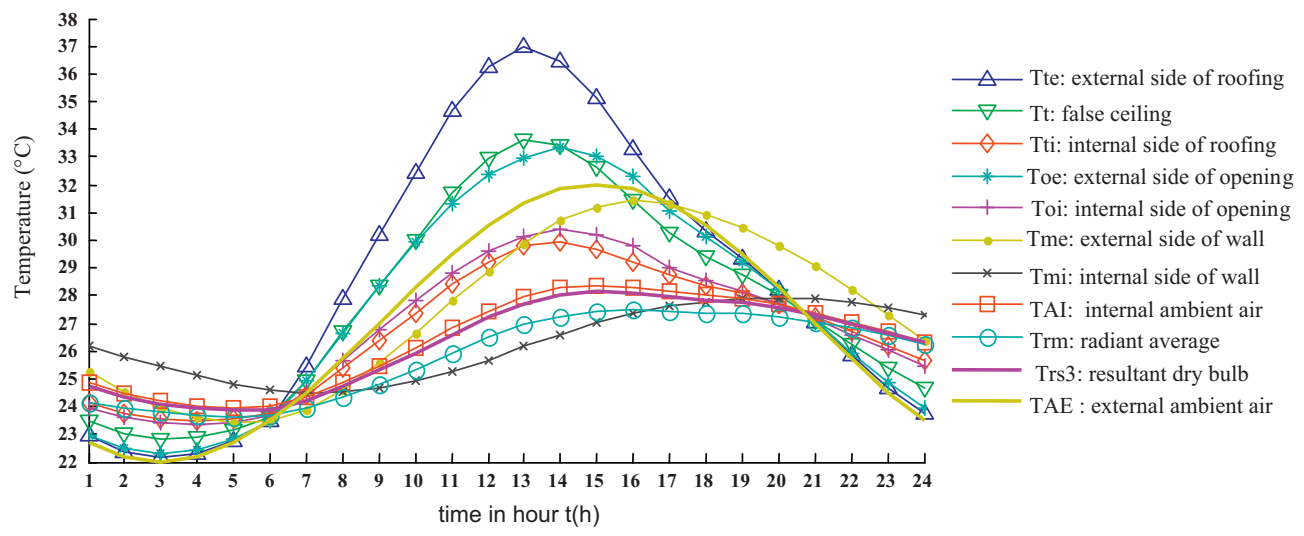

Fig. 4. Temperature profile with brick of earth and cement mortar.

dry bulb temperature of the house which is an essential criteria of comfort for the different types of house. The following results were found:

\subsubsection{Wall in wood plank}

Fig. 2 presents the evolution of the temperature in various nodes of the habitat in wood plank.

The simulation of housing in wood plank shows the following results: the roof shows the highest temperature, $37.21^{\circ} \mathrm{C}$ at $1 \mathrm{p} . \mathrm{m}$., the maximum indoor air temperature is $31.7^{\circ} \mathrm{C}$ at 3 p.m., and the dry resultant temperature is $30.8^{\circ} \mathrm{C}$ at $1 \mathrm{p} . \mathrm{m}$.

\subsubsection{Wall of hollow block concrete + cement mortar}

Fig. 3 presents the evolution of the temperature in various nodes of the habitat in hollow concrete block + cement mortar.
In this figure, the highest temperature is $37.08^{\circ} \mathrm{C}$ at 1 p.m., on the roof, the maximum temperature of the air inside is $29.68^{\circ} \mathrm{C}$ at $2 \mathrm{p} . \mathrm{m}$. and the dry resultant temperature is $29.45^{\circ} \mathrm{C}$ at $4 \mathrm{p} . \mathrm{m}$.

\subsubsection{Housing in brick of earth with cement mortar}

Fig. 4 presents the evolution of the temperature in various nodes of the habitat in brick of earth with cement mortar.

The results of this simulation show a maximum temperature at roof level of $37.01^{\circ} \mathrm{C}$ at $1 \mathrm{p}$.m. The maximum temperature of the air indoor housing is $28.36^{\circ} \mathrm{C}$ at $3 \mathrm{p}$.m. and the maximum dry resultant temperature is $28.14^{\circ} \mathrm{C}$ at 3 p.m.

\subsubsection{Analyses of the results}

It can be noticed that in Figs. 2-4, the contribution of the roof to warming the ambiance, is the most important, followed by that

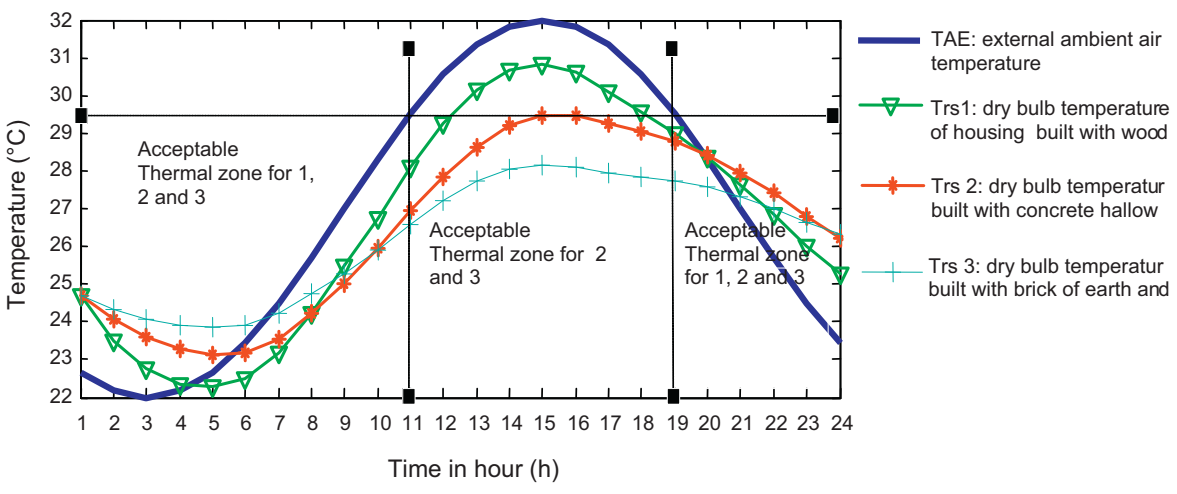

Fig. 5. Comparison of resultant dry bulb temperature of different housings. 
of openings, and finally the walls. More over, the wood plank walls are very sensible to solar radiation and hence present the highest temperature during the peak hours of the day.

\subsection{Evolution of the dry temperature}

The thermal comfort in a house depends mainly on the thermal behaviour of its envelope subjected to the climatic constraints. The essential factor of the comfort is the resultant dry bulb temperature (RDBT) which takes into account the air temperature, the air speeds and the radiation. Fig. 5 presents the evolution of dry resultant temperature of the three habitat types.

This figure shows that the maximum resultant dry temperature of housing in plank is higher than that of housing in hallow concrete blocks, and also higher than that of housing of brick earth.

It comes out of this work that the resulting dry bulb temperatures for the three simulations vary with its envelope type. Therefore, only the temperature obtained in a type 3 house is within the acceptable and tolerable thermal comfort zone in humid tropical climate.

\section{Improvement of thermal comfort in a model house}

In order to come out with a comfortable model of house, three criteria will enable us to eliminate the less adapted type of houses (thermal inertia, shading and air renewal).

\subsection{Thermal inertia}

Assuming the evolution of the temperature is periodic of period $T$; the temperature of the internal wall at a point of abscissa $x$ will be dephased [10]:

$\theta(x)=\mu(x) \theta_{0} \sin \left(\frac{2 \pi}{T}(t-\phi(x))\right)$

where the depreciation

$\mu(x)=\exp \left[-\left(\sqrt{\frac{\pi \lambda c \rho}{T}} \times \frac{x}{\lambda}\right)\right]$

And the dephasing

$\phi(x)=\frac{T}{2} \times \sqrt{\frac{\lambda \rho c}{\pi T}} \times \frac{x}{\lambda}$

The calculation of the depreciation and the lagging for the three types of wall materials used in this study with the thickness often found in the construction in Cameroon (walls in wood plank, wall in hallow concrete block, wall in clay brick) is summarized in Table 3.

These results explain why houses with wood plank walls, due to their poor thermal capacitance, insure a better comfort in the morning (between $0 \mathrm{~h}$ and $9 \mathrm{~h}$ ) and the evening (between $19 \mathrm{~h}$ and $24 \mathrm{~h}$ ), than those in clay brick wall and in hallow concrete block. Similar results are found by Hollmuller et al. [11], Arizona [12] and INSPQ [13].

Table 3

Depreciation and lagging of a heat wave through a wall over one period $T$ of $24 \mathrm{~h}$.

\begin{tabular}{llll}
\hline Building materials & Thickness $(\mathrm{cm})$ & Depreciation $(\%)$ & Lagging $(\mathrm{h})$ \\
\hline Wood plank (type 1) & 3.2 & 92 & 1 \\
$\begin{array}{c}\text { Hallow concrete block } \\
\quad \text { type 2) }\end{array}$ & 15 & 54 & 2 \\
Clay crick (type 3) & 22 & 34 & 3.5
\end{tabular}

\subsection{Shading}

Shading may be obtained by bringing vegetation around the house to reduce the surface of the house exposed to the solar flux. Vegetation should not be an obstacle to natural ventilation of the house. By covering the non-painted walls or those having dark colour by white paint, additional protection is obtained. After simulation, and taking in consideration this parameter, the following results were obtained: $30.48^{\circ} \mathrm{C}$ for type $1 ; 29.19^{\circ} \mathrm{C}$ for type 2; $28.00^{\circ} \mathrm{C}$ for type 3 . With the data chosen, the RDBT is reduced by an average $0.5^{\circ} \mathrm{C}$, but only two temperatures are found in the acceptable and tolerable thermal comfort zone $\left(T_{r s} \leq 29.4^{\circ} \mathrm{C}\right)$ in humid tropical climate. Shading used is not an effective action to obtain optimal comfort temperature for type 1 and type 2, because it reduces only the solar losses through the walls and the openings and has no impact on the solar flux received by the roof.The reduction of temperature in the house is confirmed by other authors [14-16] which provides a reduction of the ambient temperature of $1-2{ }^{\circ} \mathrm{C}$ and a reduction of solar flux received on the building from 20 to $60 \%$, due to the vegetation.

\subsection{Air renewal}

Orientation of the openings of the house in the direction of the dominant wind (South-West) which had an average velocity of $2.05 \mathrm{~m} / \mathrm{s}$ in Douala. The ratio of air renewal, noted $\mathrm{D}$, varied between 20 and 30 volumes per hours [17]. The consideration of this parameter in the simulation gave the following RDBT values: $30.35^{\circ} \mathrm{C}$ for type $1 ; 29.45^{\circ} \mathrm{C}$ for type $2 ; 28.02{ }^{\circ} \mathrm{C}$ for type 3 . The temperature of type 3 is situated in the optimal thermal comfort zone in humid tropical climate. Permanent air renewal contributes effectively to the reduction of the temperature from $0.1^{\circ} \mathrm{C}$ to $0.4^{\circ} \mathrm{C}$, but also acts on another relevant variable of comfort: hygrometry. The excess of hygrometry is in general a discomfort source and can produce condensation on the sides of the houses when its temperature is near the dew point $\left(T_{o p}=28.1^{\circ} \mathrm{C}\right.$; Hygrometry HR $\left.=80 \%\right)$. Ventilation evacuates the excess of hygrometry and contributes to the hygrometric equilibrium of the environment. The importance of this factor is also presented in others works [18]. This important factor for comfort is valid but is not practically taken in consideration in the urban maps of the constructions of towns in Cameroon.

\section{Results and discussion}

The analysis of thermal comfort and the action on parameters (inertia, shading and ventilation) for the different model houses as described in the previous section allowed to reduce the RDBT. Its value $\left(T_{\mathrm{RDBT}}\right)$ may be compared to the optimal thermal comfort temperature recommended in humid tropical climate $\left(T_{o p}=28\right.$, $1{ }^{\circ} \mathrm{C}$ ) [1]. It is described in Table 4 .

This table shows that with actions on the 3 variables (inertia, air renewal and shading) housings of type 2 and type 3 may comply with the comfort criteria listed in Section 2.

$28.1^{\circ} \mathrm{C}<$ temperature $\leq 29.4^{\circ} \mathrm{C}$

Relative humidity $\approx 80 \%$

Table 4

Thermal efficiency of the house after action.

\begin{tabular}{lrll}
\hline Type of housing & Plank & $\begin{array}{l}\text { Hallow } \\
\text { concrete block }\end{array}$ & $\begin{array}{l}\text { Brick of } \\
\text { earth }\end{array}$ \\
\hline Temperature: $T_{\mathrm{RDBT}}\left({ }^{\circ} \mathrm{C}\right)$ & 29.9 & 29.19 & 28.02 \\
Temperature difference & 1.8 & 1.09 & -0.08 \\
\hline
\end{tabular}


For the town of Douala model house of type 3 with the following characteristics: floor in cement, wall in clay brick, roof in aluminium sheet, ceiling in ply-wood, and vegetation around the house is the better model for sustainable housing. Unfortunately, this type of housing represents only $4.3 \%$ of the houses in the Littoral province. This is due to the sandy nature of Douala which makes the manufacture of local clay brick difficult. The temperature of the type 2 model house is comprised into the tolerable and acceptable thermal comfort zone in humid tropical climate and represents $34.4 \%$ of construction in the littoral province against $39.8 \%$ for type 1 which temperature is not in the recommended thermal comfort zone during peak hours of the day. Now, the synthesis figure (Fig. 5) shows that houses of type 2 and type 3 are more comfortable between 12 a.m. and 12 p.m. and between 7 p.m. and 12 a.m. where the maximal temperature of the internal environment is $28.5^{\circ} \mathrm{C}$. They are uncomfortable between 12 p.m. and 7 p.m. which corresponds to the time when the houses are not occupied. To enable the majority of household to live in the thermal comfort, an intermediary solution may be adopted between the house made in hollow concrete block (type 2) for its comfort and its stability, and the house made in wood plank (type 1) for its comfort; it is a question of building the wall with concrete block and wood plank. The simulation of a model with a mixed wall (hallow concrete block and wood plank) allowed to have simulate an intermediary comfort temperature of $29.35^{\circ} \mathrm{C}$ in a proportion of $1 / 3$ in hallow concrete block and $2 / 3$ in wood plank during the peak hours of the day. The results obtained in this work are similar to those found by many other authors in this domain [11-16,18].

\section{Conclusion}

The aim of this work was to determine, in the context of the Douala (Cameroon) housing, which would be the most sustainable option to insure thermal comfort with existing building materials.

A simulation model built, which allowed to deduce that three quarters of households made with provisional materials in the town of Douala were likely to bring thermal discomfort and for another in the tolerable thermal comfort zone.

After optimization of the thermal comfort of the house sample, it comes out from the study that the most sustainable house model for the town of Douala (dry resulting temperature $T_{\text {moy }}=28.3^{\circ} \mathrm{C}$ ) during the hours of occupation of the house (0-9 a.m. and 7 p.m. to 12 a.m.) has the following characteristics:

- floor in cement;

- mixed wall (hollow concrete block and wood plank) painted in white;

- roof in aluminium sheet, ceiling in ply-wood with ventilated air space between the roof and the ceiling;

- vegetation around the house;

- orientation of openings in the direction of prevailing wind.
An experimentation validation should be done in order to validate this model.

The choice of a relevant house model may solve the problem of thermal comfort in many of housings in the towns of a hot and humid climate. It may also contribute to the fight against poverty by the use of local building materials, and the reduction of electrical energy consumption.

\section{References}

[1] Institut National de la Statistique (INS), Tendances, Profil et Déterminants de la Pauvreté au Cameroun entre 2001-2007, Troisième Enquête Camerounaise auprès des Ménages: Rapport de Synthèse Yaoundé, Cameroun, 2008.

[2] A. Kemajou, Confort thermique en situation réelle et mesures d'économie d'énergie dans les bâtiments tertiaires au Cameroun, Thèse de doctorat, Ecole Nationale Supérieure Polytechnique de l'Université de Douala-Cameroun, 1995, 217 pp.

[3] K. Nguessam, Etude du confort thermique en ambiance non climatisée en Côte d'Ivoire, Mémoire de fin d'études, ENSP de Yamoussoukro, Côte d'Ivoire, 1992. $170 \mathrm{pp}$.

[4] N. Molle, M. Dupont, Validité d'un modèle simplifié pour la description de l'évolution de la température de l'air dans un local non climatisé, Laboratoire d'Energie Solaire, Université Antilles Guyanes-97167-Pointe-à-Pitre.

[5] Institut de l'Energie et de l'Environnement de la Francophonie, Efficacité énergétique de la climatisation en région tropicale, Conception des nouveaux bâtiments, Tome 1, Ministère de la région Wallonne, $170 \mathrm{pp}$.

[6] T. Nganya, Intérêt de l'utilisation d'isolants locaux dans l'habitat au Cameroun, Thèse de doctorat de l'école Nationale supérieure Polytechnique de YaoundéCameroun, 2000, 174 pp.

[7] Ch.P. Njupoen, Etude dynamique de l'habitat au Cameroun, Mémoire de fin d'étude du second cycle universitaire, ENSET de l'Université de DoualaCameroun, 2001, 54 pp.

[8] J. Brau, G. Krauss, J.J. Roux, Cahier des algorithmes, mallette pédagogique, CODYBA/CETHIL, INSA DE LYON, 1992.

[9] G.B. Bisseleu Fomo, Détermination d'un modèle simplifié pour la description de l'évolution de la température de l'air dans l'habitat traditionnel en bambou, Mémoire de fin d'étude du second cycle universitaire, ENSET de l'Université de Douala-Cameroun, 2001, 48 pp.

[10] Ch. Chaullaguet, P. Baratcalbal, J.P. Batellier, l'énergie solaire dans le bâtiment, EYROLLES, 1981, $201 \mathrm{pp}$.

[11] P. Hollmuller, B. Lachal, J.-M. Zgraggen, Rafraîchissement de bâtiments par déphasage thermique contrôlé, in: CISBAT'05, Lausanne, septembre, 2005, pp. 317-322.

[12] Arizona Solar Center, Passive Solar Heating and Cooling, 2009.

[13] Institut National de Santé Publique du Québec (INSPQ), Mesures de lutte aux îlots de chaleur urbains, 2009.

[14] CRES, Concevoir des espaces extérieurs en environnement urbain: une approche bioclimatique, Projet Rediscovering the Urban Realm and Open Spaces, CRES, Département des bâtiments, 2004.

[15] A. Khecharem, Modélisation thermique des batiments: évaluation des principaux critères architecturaux sur la qualité thermique des bâtiments, Mémoire de Master Design Global soutenue à l'Ecole Nationale Supérieure d'Architecture de Nancy, 2009, 86 pp.

[16] B. Moujalled, Modélisation dynamique du confort thermique dans les bâtiments naturellement ventilés, Thèse de Doctorat soutenue à l'Institut des Sciences Appliquées de Lyon, 2007, 330 pp.

[17] Institut de l'Energie des Pays ayant en commun l'usage du Français, Atelier prisme - maîtrise de l'énergie dans les bâtiments, IEPF, Yaoundé, 1993. 418 pp.

[18] R.O. Dilshan, A.M. Roshida, H.B. Mohd, Tropical Building Design Principles for Comfortable Indoor Environment, Faculty of Built Environment, Universiti Teknologi Malaysia, 2008, 103 pp. 